\title{
An erythrocyte-specific protein that binds to the poly(dG) region of the chicken $\beta$-globin gene promoter
}

\author{
Catherine D. Lewis, ${ }^{1}$ Stephen P. Clark, ${ }^{1}$ Gary Felsenfeld, ${ }^{1}$ and Hannah Gould ${ }^{2}$ \\ ${ }^{1}$ Laboratory of Molecular Biology, National Institute of Diabetes, and Digestive and Kidney Diseases, Bethesda, Maryland \\ 20892 USA; ${ }^{2}$ Department of Biophysics, King's College, London WC2B 5RL UK
}

\begin{abstract}
The promoter region of the chicken adult $\beta$-globin gene contains a sequence of 16 deoxyguanosine residues located at a nucleosome boundary in tissues where the gene is inactive. In definitive erythrocytes that express the $\beta$-globin gene, the nucleosome is displaced, the G-string and adjacent sequences are occupied by sequencespecific DNA-binding proteins, and a nuclease hypersensitive domain is generated in this region. To gain insight into the role of the G-string in this series of events, we have examined the proteins that bind to it. Using the gel mobility shift assay and a monoclonal antibody that blocks specific binding to the G-string, we have identified a specific protein, BGP1, that is found only in chicken erythroid cells and appears at the same time, or shortly before, the changes in chromatin structure. The antibody interacts strongly with BGP1 and cross-reacts weakly with Sp1. Although both BGP1 and Sp1 require $\mathrm{Zn}^{2+}$ for their DNA-binding activity, these proteins differ in their binding-site specificities, chromatographic properties, and molecular weights. In contrast to Sp1, which is found in a wide variety of cell types, BGP1 is restricted to erythrocytes and is most abundant in definitive erythrocytes. Thus, its presence corresponds to the tissue- and stage-specific occupancy of the G-string in vivo.
\end{abstract}

[Key Words: $\beta$-globin gene; erythrocyte-specific factors; G-string; BGP1; Sp1]

Received January 28, 1988; revised version accepted May 9, 1988.

The activation of the adult $\beta$-globin gene during chicken erythroid development is associated with characteristic changes in chromatin structure. The switch from cells expressing the embryonic $\epsilon$ - and $\rho$-globin to those expressing the adult $\beta$-globin gene occurs between 5 and 9 days after fertilization of the egg (Landes and Martinson 1982; Landes et al. 1982; Villeponteau et al. 1982). At this time, a nuclease hypersensitive domain, which reflects the loss of a nucleosome, first appears in the promoter region of the $\beta$-globin gene (McGhee et al. 1981; Emerson and Felsenfeld 1984). This region contains at least six discrete sequence elements (Fig. 1) that are protected by protein in footprinting experiments: the Gstring, the palindrome/globin consensus (CACCC) sequence, the polypyrimidine tract, the CAAT box, the polypurine tract, and the TATA box. The G-string overlaps with the core consensus sequence, GGGCGG, for the transcription factor Spl (Briggs et al. 1986; Kadonaga et al. 1986). The palindromic and CACCC sequences may also overlap, although they bind distinct proteins independently of each other (C.D.Lewis and S.P.Clark, unpubl.). The CACCC sequence is required for high levels of globin gene transcription in fibroblasts (Dierks et al. 1983; Myers et al. 1986). The CAAT and TATA boxes are binding sites for general eukaryotic transcription factors that have been studied extensively in other systems (Breathnach and Chambon 1981). The polypurine and polypyrimidine tracts are binding sites for the ubiquitous transcription factor Spl, as will be shown below.

The G-string has unusual DNA structural properties dependent on the level of supercoiling (Nickol and Felsenfeld 1983; Schon et al. 1983; Kohwi-Shigematsu and Kohwi 1985), and exhibits special properties with respect to chromatin structure as well. In cells that do not express $\beta$-globin, the G-string is located at the border of a DNA linker region with a nucleosome on the 3 ' side of the sequence (Jackson 1986), and the G-string is accessible to nuclease. In definitive erythrocytes that display the nucleosome-free hypersensitive domain, the Gstring is protected from nuclease attack by the binding of specific nonhistone protein (Jackson and Felsenfeld 1985 |, which is also seen in vitro with the cloned gene and partially purified erythrocyte nuclear proteins (Emerson et al. 1985; Plumb et al. 1986). This suggested to us that the interplay between the binding of an erythrocyte-specific G-string-binding factor, DNA conformation, and nucleosome stability might play a role in generation of the hypersensitive domain and the derepression of the $\beta$-globin gene. As the first step in the examination of this possibility, we therefore undertook the identification of factors that bind to the G-string.

In this paper we describe the properties of the major erythrocyte G-string-binding protein, which we call BGP1. Our characterization is achieved by measurement of DNA binding that can be blocked by a monoclonal 


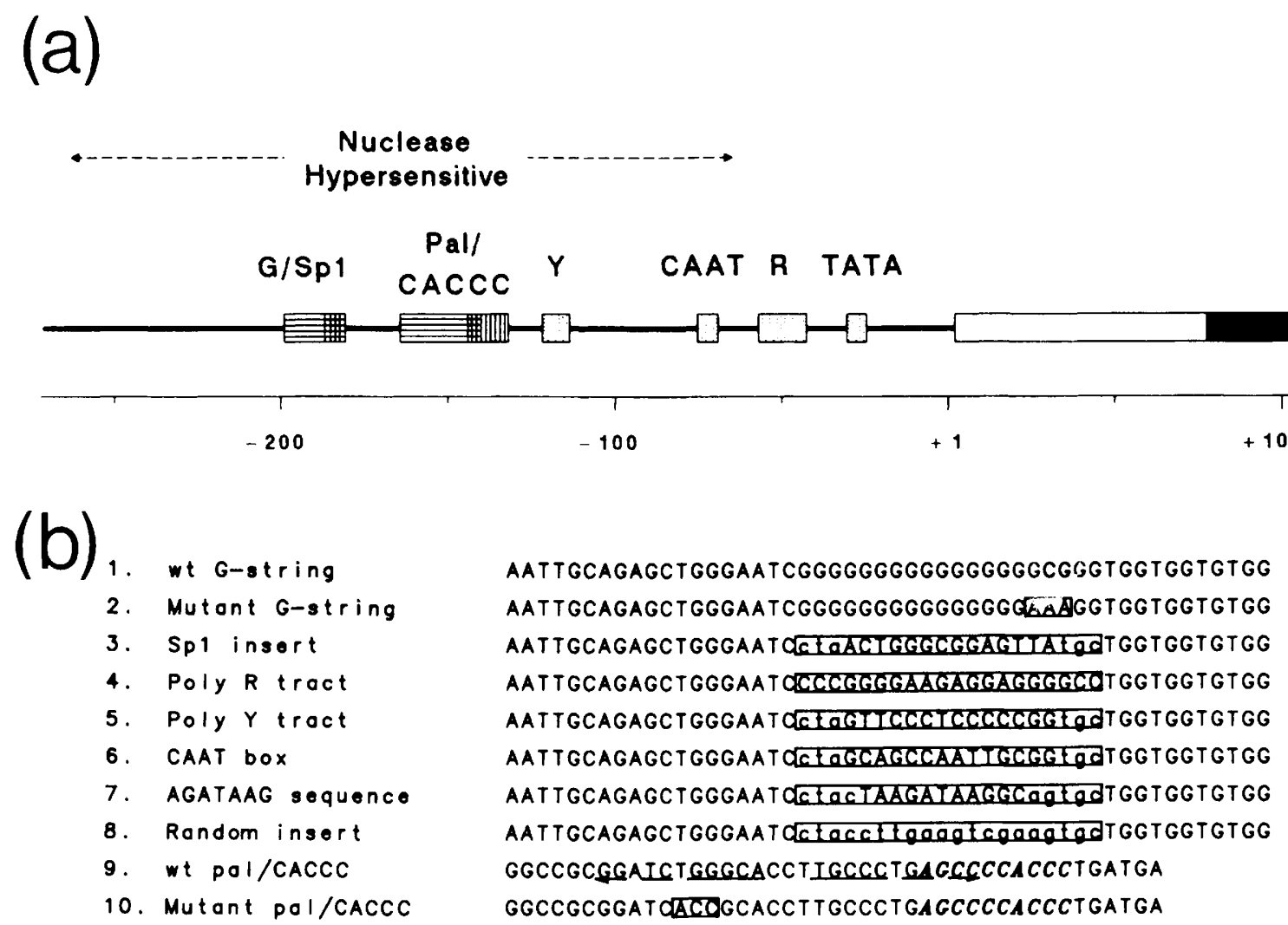

Figure 1. (a) Outline of the chicken $\beta$-globin promoter region. Transcriptional consensus sequences and regions to which proteins are known to bind are indicated. (G/Spl) Overlapping G-string (16 consecutive deoxyguanosine residues) and possible Spl site; (Pal/ $\mathrm{CACCC}$ ) overlapping inverted repeat and $\beta$-globin consensus sequence; $(\mathrm{Y})$ polypyrimidine stretch; $(\mathrm{R})$ polypurine stretch. Transcription starts at position +1 (open box), and the solid box represents the translated region. (b) Sequences of the double-stranded oligonucleotides used in the gel mobility shift assays. Changes from the wild-type (wt) sequences are enclosed in boxes, and positions derived from a random oligonucleotide (line 8 ), used to make the lengths equal, are shown in lowercase. The palindrome (pal) sequence is underlined in 9 and the $\beta$-globin consensus sequence is indicated by italics.

antibody $(\mathrm{mAb})$ against the protein. The G-string terminates with the core consensus for the transcription factor Spl (GGGCGG; Kadonaga et al. 1986). We find that BGPl bears a structural similarity to $\mathrm{Spl}: \mathrm{Spl}$ is recognized weakly by the monoclonal antibody, and both proteins require zinc for activity. However, BGP1 and Spl differ significantly in other respects, including affinity for the G-string (BGP1 >>Sp1), chromatographic properties on DNA-cellulose, molecular weight, and tissue specificity. Most importantly, unlike Spl, which is found in all tissues in about equal abundance, BGP1 is restricted to definitive erythrocytes and increases in concentration during the critical interval of 5-9 days after fertilization, during which the switch in globin gene expression occurs.

\section{Results}

\section{Production and preliminary screening of hybridomas}

To characterize proteins binding to the G-string, mAbs were generated against specific DNA-binding proteins present at low abundance in a mixture. Proteins extracted from erythrocyte nuclei were purified by DNAcellulose chromatography (see Materials and methods) and enriched for specific binding factors by DNA affinity chromatography on a column made with a plasmid containing a 470-bp insert from the $5^{\prime}$-flanking region of the chicken $\beta$-globin gene, including the hypersensitive domain (Fig. 1). This resulted in enrichment of these factors by 10 - to 15 -fold, relative to the DNA-cellulose alone (data not shown).

Two mice were injected with the proteins obtained from the DNA-cellulose column, and the second mouse was boosted with the fraction from the affinity column. The injection of the enriched protein elevated the serum titer 50 -fold against the specific proteins, whereas the serum titer against the less purified protein was raised by a factor of only 2. After fusion of spleen cells with a mouse myeloma, mouse I yielded 1 , and mouse II yielded 12 hybridomas that screened positive with both the DNA-cellulose and the affinity-purified protein fractions and survived expansion. Five of these were subcloned, of which four produced enough antibody $(>10 \mu \mathrm{g} / \mathrm{ml})$ for further analysis.

$D N A$-binding assay and identification of a $m A b$ that blocks binding of a protein factor to the G-string

The gel mobility shift assay (Fried and Crothers 1981; Garner and Revzin 1981) was adapted to detect the inter- 
action of antibodies with DNA-binding proteins. Cell extracts in the presence or absence of antibody were mixed with specific DNA fragments and subjected to gel electrophoresis. Antibody binding should either lower the mobility of the DNA-protein complex or block its formation. The target DNA fragments were radiolabeled, double-stranded synthetic oligonuceleotides in which the binding site of interest was substituted into the wild-type G-string to control for the effects of fragment length and flanking DNA sequence (Fig. 1). In addition to the wild-type G-string, a mutant was tested that should eliminate any Spl binding (Gidoni et al. 1985) by changing the central GCG to AAA. Other sequences substituted were the polypyrimidine stretch, the CAAT box, the polypurine stretch, the AGATAAG sequence from the $\rho$ - and $\alpha$-globin promoter regions (Kemper et al. 1987), a high-affinity Spl site from region III of the SV40 21-bp repeat (Kadonaga et al. 1986), and a random sequence to serve as a negative control. The palindrome/CACCC sites were on slightly shorter oligonucleotides; one contained the wild-type sequence, and the other contained a 3-bp mutation in the palindrome that allows binding only to the CACCC sequence (S.P. Clark, unpubl.).

Figure 2 illustrates the effect of the four mAbs on the gel-shift patterns obtained with the G-string probe. Only one has a significant effect on the pattern of DNA-protein complexes. This antibody (2B10-1F8) blocks the formation of a major protein complex, which we call BGPX1 ( $\beta$ G-string protein complex 1), indicated by the solid arrow. The abundance of two other complexes of greater mobility is augmented as the antibody displaces protein from BGPX1. Thus, a number of proteins in erythrocyte extracts bind to this sequence; the protein recognized by $2 \mathrm{~B} 10-1 \mathrm{~F} 8$ is the one we call $\mathrm{BGPl}$.

\section{Effect of $m A b 2 B 10-1 F 8$ on other binding factors}

To determine whether the inhibition of G-string binding by $\mathrm{mAb} 2 \mathrm{~B} 10-1 \mathrm{~F} 8$ is specific, the effect of this $\mathrm{mAb}$ on a number of DNA-binding proteins was examined (Fig. 3).
The first lane in each panel shows the mobility shift in the absence of $\mathrm{mAb}$; the subsequent lanes show the effect of a twofold serial dilution of the $\mathrm{mAb}$. Each binding site has a distinct pattern of shifted bands, indicative of the different factors that bind. However, the Sp1, polypurine, and polypyrimidine probes give shifted bands of identical mobility when run side by side, as does the uppermost CACCC complex. Furthermore, pure Spl from HeLa cells (gift of J. Kadonaga and R. Tjian) forms a complex of the same mobility (data not shown). As expected, the mAb 2B10-1F8 inhibits binding to the Gstring (Fig. 3). It also inhibits binding by chicken and human extracts to the Spl fragment (Fig. 3B,C), by purified HeLa cell Spl to the Sp1 fragment (results not shown), and by the chicken extract to the CACCC (Fig. 3D) and polypurine and polypyrimidine (not shown) fragments. The inhibition of CACCC binding is selective for the uppermost complex and is more pronounced in other experiments. In contrast, the antibody has no effect on the binding of the palindrome, CAAT, or AGATAAG proteins to their sites (Fig. 3,E-G), indicating that the antibody does not interfere with protein-DNA binding by some nonspecific mechanism. Although BGP1 and Spl can be distinguished by a variety of criteria shown below, they must have a shared structure that is recognized by this mAb. However, the polypurine, polypyrimidine, and uppermost CACCC complexes cannot be distinguished from the Spl complex. Data presented below confirm that $\mathrm{Spl}$ is the protein involved in all of these interactions.

Although the mAb 2B10-1F8 recognizes both BGP1 and $\mathrm{Spl}$, the affinity of the antibody for the proteins is not the same. An estimate of this difference was obtained by determining the concentration of antibody required to saturate the two antigens by ELISA, gel-shift assay, and Western blotting. BGP1 required 4- to 8-fold less antibody than $\mathrm{Sp} 1$ to reduce DNA binding by $50 \%$ in the gel-shift assay; ELISA and Western blotting, however, indicated that the antibody had an affinity at least 20-fold higher for BGP1.
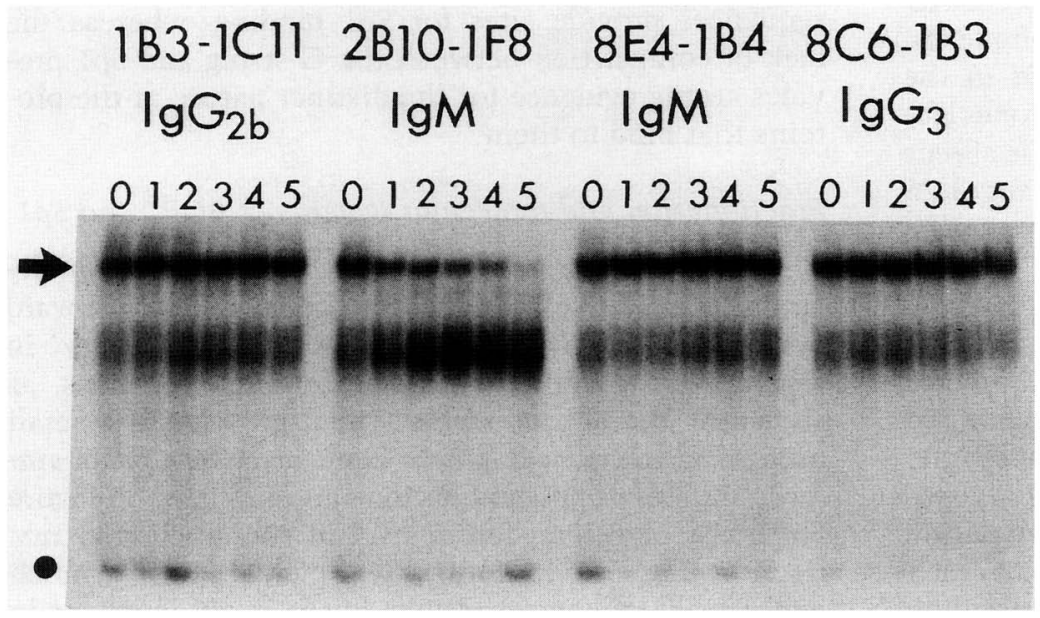

Figure 2. Effect of four mAbs on the activity of $\mathrm{G}$-string-binding proteins. Each reaction contained DNA, DNA-cellulose purified G-stringbinding proteins, and a variable amount of unpurified mAb supernatants. For each panel, the gel-shift pattern where no antibody is added is shown in lane 0 . (Lanes 1-5) The effect of adding $1-5 \mu \mathrm{l}$ of each of four antibody supernatants: 1B3-1C11, 2B10-1F8, 8E4-1B4, and 8C6-1B3. (•) The position of naked DNA; $(\rightarrow)$ the position of the G-string complex (BGPXI) inhibited by the antibody 2B10-1F8. 


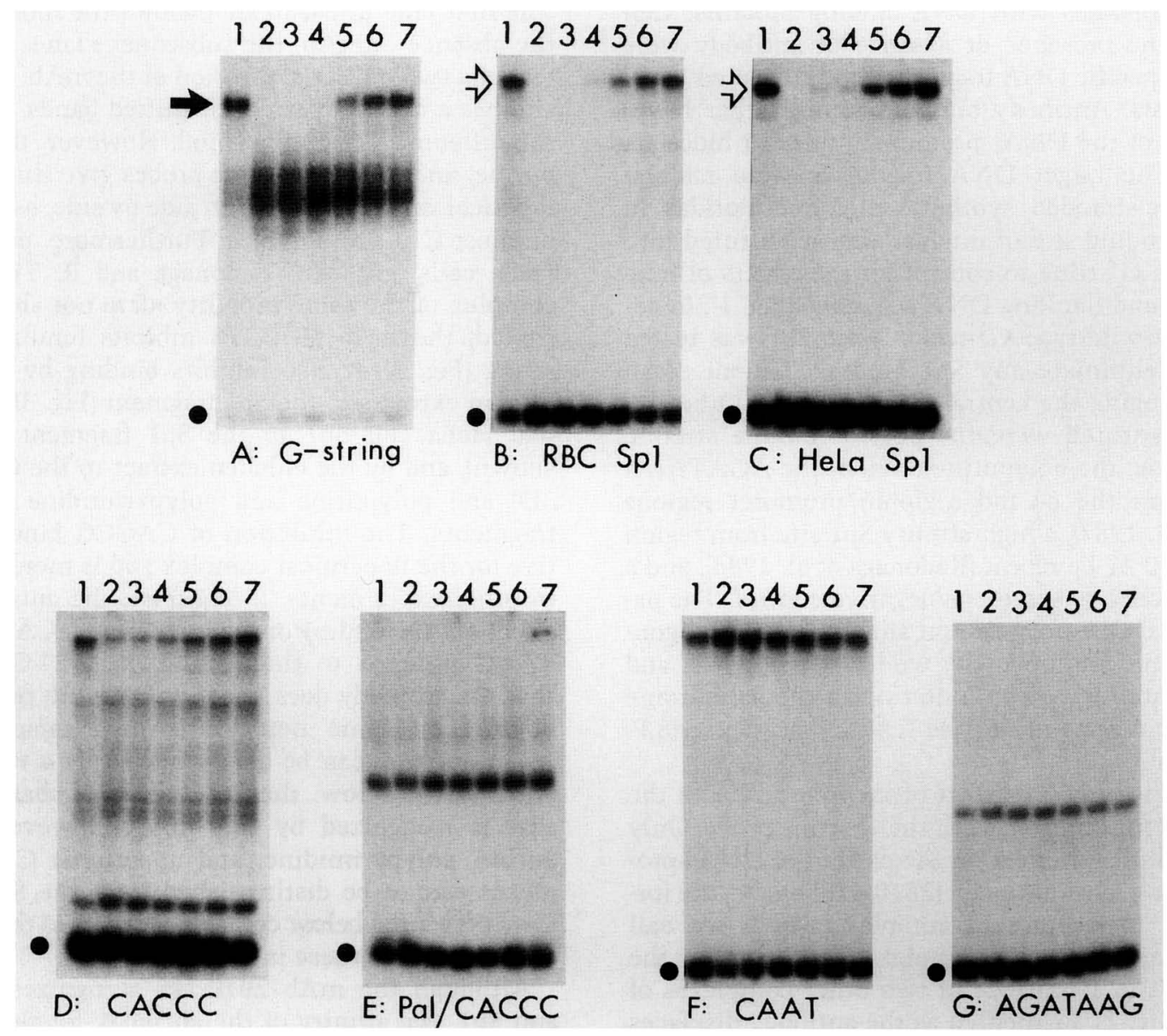

Figure 3. Effect of mAb 2B10-1F8 on protein binding to various DNA fragments. Protein and then DNA were added to twofold serial dilutions of antibody (lanes 2-7) or to buffer (lane 1) and electrophoresed on polyacrylamide gels. All assays were done with an adult chicken erythrocyte nuclear extract that had been partially purified by DNA-cellulose chromatography, except $C$, where an unfractionated $400 \mathrm{~mm} \mathrm{NaCl} \mathrm{HeLa} \mathrm{nuclear} \mathrm{extract} \mathrm{was} \mathrm{used.} \mathrm{The} \mathrm{amount} \mathrm{of} \mathrm{protein} \mathrm{was} \mathrm{chosen} \mathrm{to} \mathrm{give} \mathrm{suitable} \mathrm{shifted} \mathrm{bands.} \mathrm{Binding}$ assays were done in the presence of $100 \mathrm{ng}$ poly[d(AT)], except for the HeLa extracts, where $1500 \mathrm{ng}$ was used. The DNA probes correspond to those shown in Figure 1 as follows: $(A)$ Probe 1, wild-type G-string; $(B$ and $C)$ probe 3 , Spl insert $(D)$ probe 10 , mutant palindrome/CACCC $(E)$ probe 9, wild-type palindrome/CACCC; $(F)$ probe 6, CAAT box; $(G)$ probe 7 , AGATAAG sequence. SplDNA complexes are indicated with open arrows, whereas closed arrows mark the major G-string complex BGPXI. $(\bullet \mid$ Free DNA.

\section{DNA-binding competition assays}

To examine the sequence specificity of the proteins responsible for several of the DNA-protein complexes, gel mobility shift experiments were performed in the presence of an excess of various unlabeled oligonucleotides (Fig. 4; Table 1). In each panel, competitor is absent in the first lane and present at between 80 and 1.25 times the labeled oligonucleotide concentration in the remaining lanes.

Formation of complexes with the labeled G-string probe is competed only by the mutated G-string that lacks the Spl site. The wild-type G-string competes identically (not shown). In contrast, the complex formed by the labeled $\mathrm{Sp} 1$ probe is only slightly competed by the G-string, but is competed efficiently by the Spl and polypurine fragments. Similarly, the labeled polypurine and polypyrimidine complexes are competed by each other and by the Spl fragment, but the polypyrimidine fragment competes less well. This pattern of competition indicates that the polypurine and polypyrimidine sequences provide sites for $\mathrm{Spl}$ binding, whereas the lack of competition between the G-string and Spl provides strong evidence for the distinct nature of the proteins that bind to them.

\section{Fractionation and molecular weights of BGP1 and Sp1}

The nuclear extract was fractionated on a doublestranded DNA-cellulose column as a first step toward purification of BGP1 (Fig. 5). The column is effective in separating the complex mixture of input proteins, as shown by the elution of individual proteins in a small number of fractions (Fig. 5a). The concentrations of ammonium sulfate in the fractions are indicated in Figure $5 \mathrm{~b}$. BGPl elutes predominantly in the single $185 \mathrm{~mm}$ fraction (Fig. 5d). In contrast, Spl elutes over a much wider range of concentrations but is most abundant in 


\section{Unlabelled Competitor}

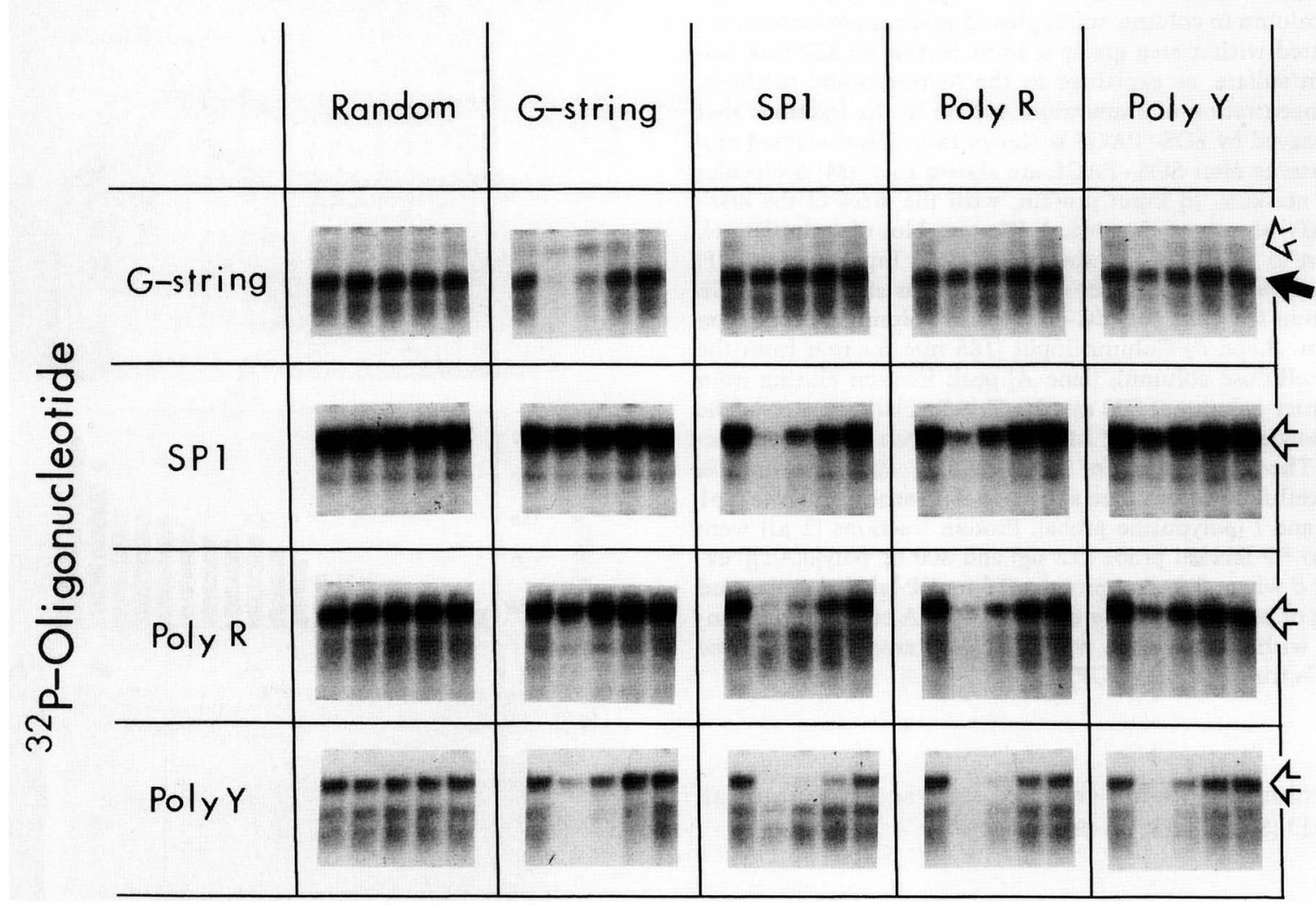

Figure 4. Competition for specific binding proteins between different DNA fragments. The ${ }^{32}$ P-labeled probe $(0.2 \mathrm{ng})$ indicated at the left was mixed with the unlabeled test competitor shown at the top: (Lane 1) no test competitor; (lane 2) $16 \mathrm{ng}$; (lane 3) $4 \mathrm{ng}$; (lane 4) 1 ng; (lane 5) $0.25 \mathrm{ng}$. DNA-cellulose-purified erythrocyte nuclear extract was then added. DNA-protein complexes of interest are indicated by open arrows (Sp1X) and closed arrows (BGPX1). Note that the ${ }^{32}$-labeled G-string probe contains the wild-type sequence, whereas the unlabeled G-string competitor had been mutated so that it lacks the Spl site (Fig. 1b).

the 125-150 mM fractions (Fig. 5e). The polypurine- (Fig. 5f) and polypyrimidine- (not shown) binding proteins elute with a profile identical to that of $\mathrm{Spl}$, as does the protein that forms the uppermost CACCC complex (not shown).

Table 1. Competition for binding by various sites

\begin{tabular}{|c|c|c|c|c|c|}
\hline \multirow[b]{2}{*}{$\begin{array}{l}\text { Binding } \\
\text { site }\end{array}$} & \multicolumn{5}{|c|}{ Competition } \\
\hline & random & $\begin{array}{l}\text { G-string } \\
\text { mutant }\end{array}$ & Spl & $\begin{array}{l}\text { poly- } \\
\text { purine } \\
\text { (R) }\end{array}$ & $\begin{array}{l}\text { poly- } \\
\text { pyrimidine } \\
\qquad(\mathrm{Y})\end{array}$ \\
\hline \multicolumn{6}{|l|}{ Wild-type } \\
\hline G-string & - & ++ & - & $+1-$ & $+1-$ \\
\hline Spl & - & - & ++ & ++ & + \\
\hline Polypurine (R) & - & $+1-$ & ++ & ++ & + \\
\hline \multicolumn{6}{|l|}{ Polypyrimidine } \\
\hline (Y) & - & ++ & +++ & ++ & ++ \\
\hline
\end{tabular}

Summary of competition shown in Figure 4.

Note that the ${ }^{32} \mathrm{P}$-labeled G-string probe in the first row has the wild-type sequence and contains the Spl site, but the G-string competitor in column 3 is the mutant that lacks this site.
A Western blot of the column fractions, probed with $\mathrm{mAb} 2 \mathrm{~B} 10-1 \mathrm{~F} 8$, is shown in Figure 5c. The antibody binds to a number of proteins in the nuclear extract that was applied to the column (lane I). The proteins at 120 $\mathrm{kD}$ do not bind tightly to the column because they elute at or below $75 \mathrm{~mm}$. Binding to the $33-$ and $30-\mathrm{kD}$ proteins is the result of a nonspecific interaction with one of the reagents used in developing the Western blot (not shown); the $72-\mathrm{kD}$ protein recognized in the nuclear extract has not been identified. Upon longer exposure of the autoradiogram, the $100-\mathrm{kD}$ component can be seen to elute over a wide concentration range but is barely visible in the 125-150 mm fractions in Figure 5c. This protein must be Spl because the pattern on the Western blot parallels that of Spl binding. The $66-\mathrm{kD}$ band appears as a doublet in the $185 \mathrm{~mm}$ fraction at a point corresponding exactly to the peak of G-string-binding activity shown in Figure $5 \mathrm{~d}$, suggesting that at least one of these proteins is responsible for this binding activity. In fact, further purification of the peak binding activity from the $185 \mathrm{~mm}$ fraction of the DNA-cellulose column on a poly(dG-dC) affinity column gives results consistent with this identification. As shown in Figure $5 \mathrm{c}$ (lane A), the peak activity fraction that elutes from the af- 
Figure 5. Separation of DNA-binding activities in the erythrocyte nuclear extract by DNA-cellulose column chromatography. The crude nuclear extract was applied to the DNA-cellulose column in column buffer plus $25 \mathrm{~mm}$ ammonium sulfate and eluted with a step gradient from $50 \mathrm{~mm}$ to $250 \mathrm{~mm}$ ammonium sulfate, as explained in the Materials and methods. The concentration of ammonium sulfate in the fractions that were assayed by SDS-PAGE is shown in $b$. Silver-stained protein patterns after SDS-PAGE are shown in $a$. (M) Molecular weight markers; (I) input protein, with the sizes of the standards $(\mathrm{kD})$ shown at the side. A Western blot of a similar gel, using $\mathrm{mAb} 2 \mathrm{~B} 10-1 \mathrm{~F} 8$, is shown in $c$. (I) Input protein; $|\mathrm{F}|$ column flow-through. Silver-stained patterns after SDS-PAGE of fractions from the poly(dG-dC) affinity column are shown on the right. (Lane $\left.I^{\prime}\right)$ Column input ( $185 \mathrm{~mm}$ fraction from the DNA-cellulose column); (lane A) peak fraction eluting from the affinity column at $500 \mathrm{~mm} \mathrm{NaCl}$ (S.P. Clark, in prep.). The major bands are at $66-67 \mathrm{kD}$ and elute with the binding activity. The distribution of DNA-binding activities on the DNA-cellulose column are shown in $d$ (G-string probe), $e$ (Spl probe), and $f$ (polypurine probe). Protein fractions $(2 \mu \mathrm{l})$ were added to ${ }^{32} \mathrm{P}$-labeled probe $(0.2 \mathrm{ng})$ and $300 \mathrm{ng}$ poly[d(AT)], except for $d$ where $0.5 \mu$ l of protein, $0.5 \mathrm{ng}{ }^{32} \mathrm{p}$-labeled probe, and $3000 \mathrm{ng}$ of poly[d(AT)] were used. Spl-DNA complexes are indicated with open arrows, whereas closed arrows indicate the major G-string complex BGPXI.

finity column is highly enriched for a set of proteins at 66-67 kD (S.P. Clark, in prep.).

\section{BGP1 and chicken Sp1 require zinc for activity}

The antigenic cross-reactivity between BGPI and chicken Spl suggests that the epitopes recognized in these two proteins are related. Because HeLa cell Spl is known to be a zinc finger protein (Kadonaga et al. 1987), we examined whether the chicken counterpart of $\mathrm{Spl}$ and BGPI require zinc for binding activity.

Figure 6a shows the effect of the divalent cation chelating agent $o$-phenanthroline (Fig. 6a, A) and of its inactive analog $p$-phenanthroline (Fig. 6a, B) on the gel-shift pattern with the G-string probe. Only o-phenanthroline, at concentrations between 1 and $2 \mathrm{~mm}$, inhibits the formation of the BGPl complex (solid arrow). Chicken Spl is inhibited at a similar concentration (Fig. $6 \mathrm{a}, \mathrm{C}$ ), as is HeLa cell Spl (panel D). The palindrome (Fig. 6a, E), AGATAAG (Fig. 6a, F), and CAAT (Fig. 6a, H) proteinbinding activities are not inhibited by the chelation of divalent cations. All the various CACCC-binding proteins are, however, inhibited.

Reconstitution experiments were carried out to establish the specificity of the metal ion requirement (Fig. 6b). $\mathrm{Zn}^{2+}, \mathrm{Co}^{2+}, \mathrm{Mn}^{2+}, \mathrm{Fe}^{2+}$, and $\mathrm{Mg}^{2+}$ were tested in the range of $0.1 \mu \mathrm{M}-2 \mathrm{mM}$. $\mathrm{Zn}^{2+}$ completely restores the G-string-binding activity of the erythrocyte protein mixture at concentrations between 5 and $10 \mu \mathrm{M}$, although it inhibits binding activity above $1 \mathrm{~mm}$ (not shown). $\mathrm{Co}^{2+}$ at concentrations of $100 \mu \mathrm{M}$ or higher results in a partial restoration of activity, as it does with the known zinc finger protein TFIIIA (Hanas et al. 1983; Berg 1986). None of the other metals is active. The activity of

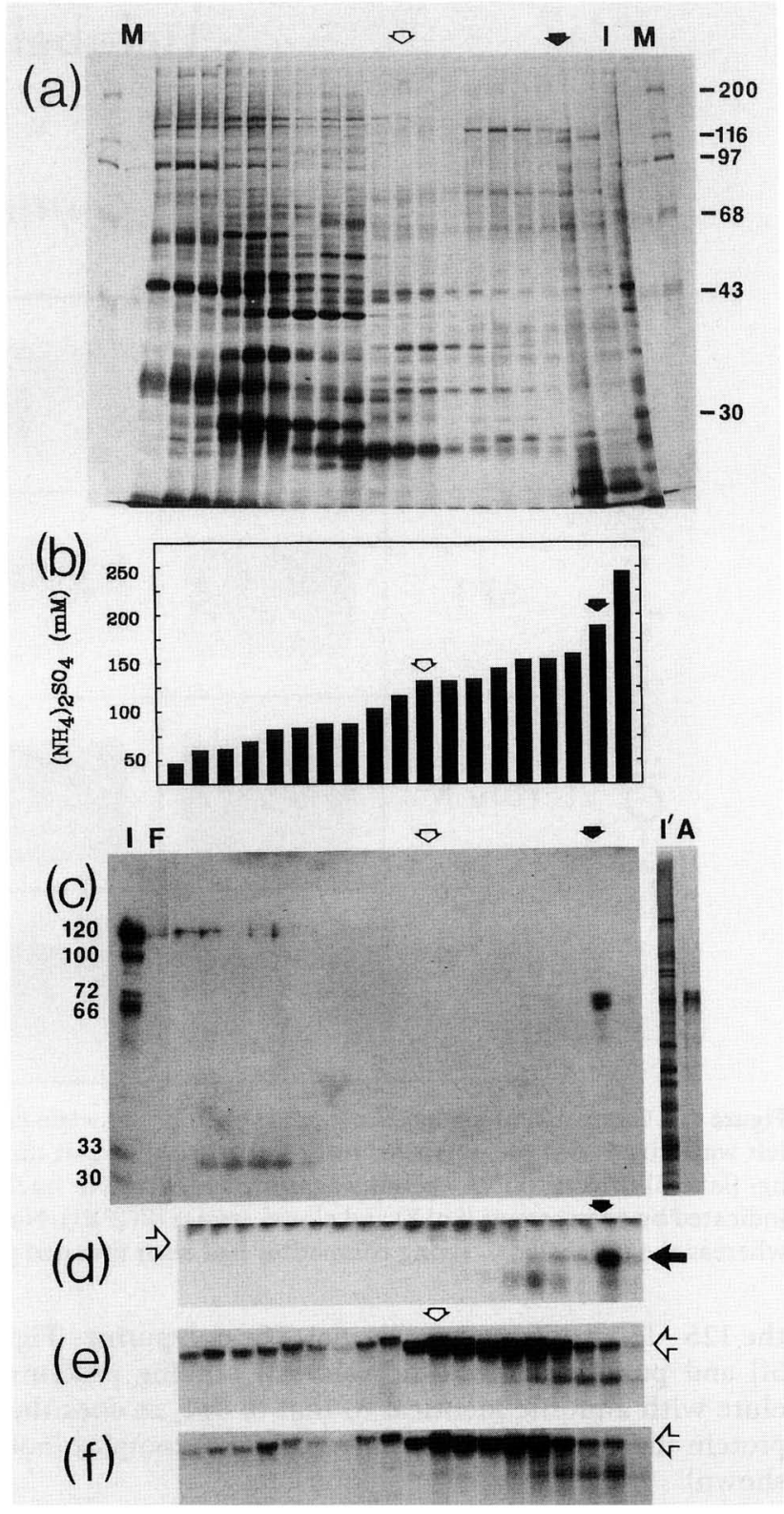

human and chicken $\mathrm{Spl}$ is restored by $\mathrm{Zn}^{2+}$ under exactly the same conditions as BGP1 (not shown).

\section{Tissue specificity of $B G P 1$}

The distribution of BGP1 in various nonerythroid cells and in embryonic erythrocytes at several stages of development was examined (Fig. 7). The criteria used to assess the presence of BGP1 activity in a given cell type were the presence of a complex at the position of BGPX1 in a gel-shift assay, and inhibition of that complex by preincubation with the mAb $2 \mathrm{~B} 10-1 \mathrm{~F} 8$. Each extract was tested further for the presence and relative abundance of $\mathrm{Spl}$ activity to control for differences in protein concentration and general binding activity. Only the adult, 12day, and 9-day chicken erythrocytes show a prominent 
band at the position of BGPXl (Fig. 7A); the 5-day extract shows a weaker band at this position. Extracts from chicken heart and from the chicken erythroid precursor cell line HD3 (Beug et al. 1982) do not form this complex, nor do extracts from a murine pre-B lymphoma line (38C-13) or from HeLa cells. Extracts made from chicken

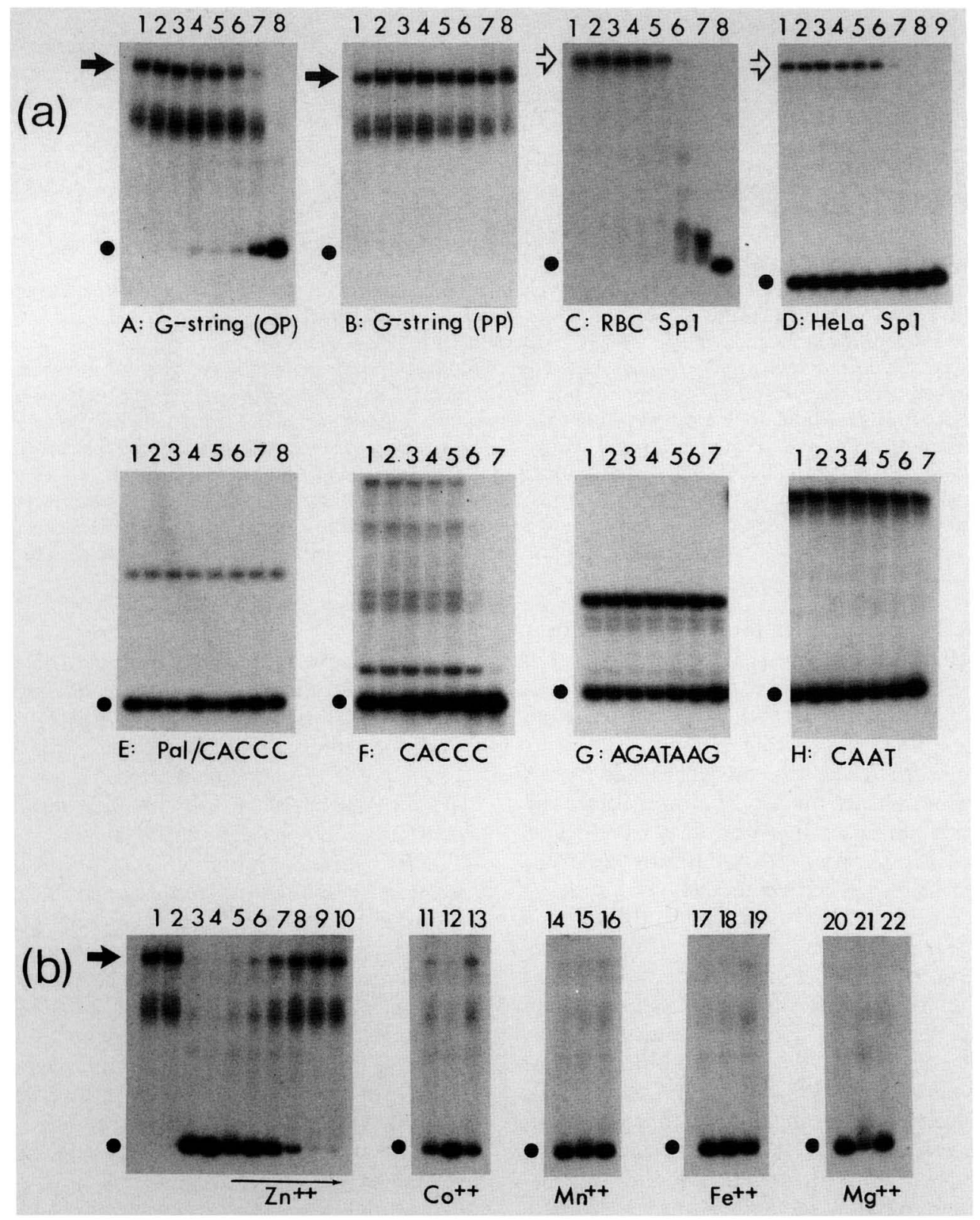

Figure 6. Metal ion requirement for G-string and Spl binding. (a) The effect of metal chelation by $(1,10)$-o-phenanthroline (OP) on the factors binding to the $5^{\prime}$-flanking region of the $\beta$-globin gene was assessed by abolition of the gel shift pattern. DNA-cellulose-purified material was used as a source of proteins to bind to the indicated probes, except for $E$, where the protein had been purified further by ion-exchange chromatography, and $D$, where a crude $400 \mathrm{mM} \mathrm{NaCl} \mathrm{HeLa} \mathrm{nuclear} \mathrm{extract} \mathrm{was} \mathrm{employed.} \mathrm{Protein} \mathrm{extracts} \mathrm{were}$ preincubated with OP before addition of the DNA, except for lane 0 , where no OP was used. In $A, C$, and $E$, lanes 2-8 show the effect of $0.03,0.06,0.12,0.25,0.5,1.0$, and $2.0 \mathrm{mM}$ OP. $B$ is identical, except that $(4,7)$-p -phenanthroline (PP) was substituted for OP. In $F, G$, and $H$, lanes 2-7 show the effect of $0.06,0.12,0.25,0.5,1.0$, and $2.0 \mathrm{mM} \mathrm{OP}$, and in $D$, lanes 2-9 show the effect of $0.015,0.03,0.06$, $0.12,0.25,0.5,1.0$, and $2.0 \mathrm{mM}$ OP. ( $\bullet$ ) The position of the naked DNA; (solid arrow) the G-string factor complex (BGPX1); (open arrow) the position of the Spl complex (SplX). (b) Reconstitution of G-string acitivity by zinc. The effect of adding various metals to a protein extract that had been depleted with OP was tested. A protein fraction enriched in BGPl-binding activity (vertical solid arrow, Fig. 5) was preincubated with $1.5 \mathrm{mM}$ OP and divided into aliquots to which various divalent cations were added. After a 5-min incubation, the DNA was added. (Lanes 1 and 2) The control pattern when no OP was added; (lanes 5-10) the effect of adding back 0.1, $1.0,5.0,10,50$, and $100 \mu \mathrm{Mn}^{2+}$; (lanes 11-13,14-16, 17-19, and 20-22) the effect of adding back 0.1, 10, and $100 \mu \mathrm{M}$ of $\mathrm{Co}^{2+}, \mathrm{Mn}^{2+}$, $\mathrm{Fe}^{2+}$, or $\mathrm{Mg}^{2+}$, respectively. 


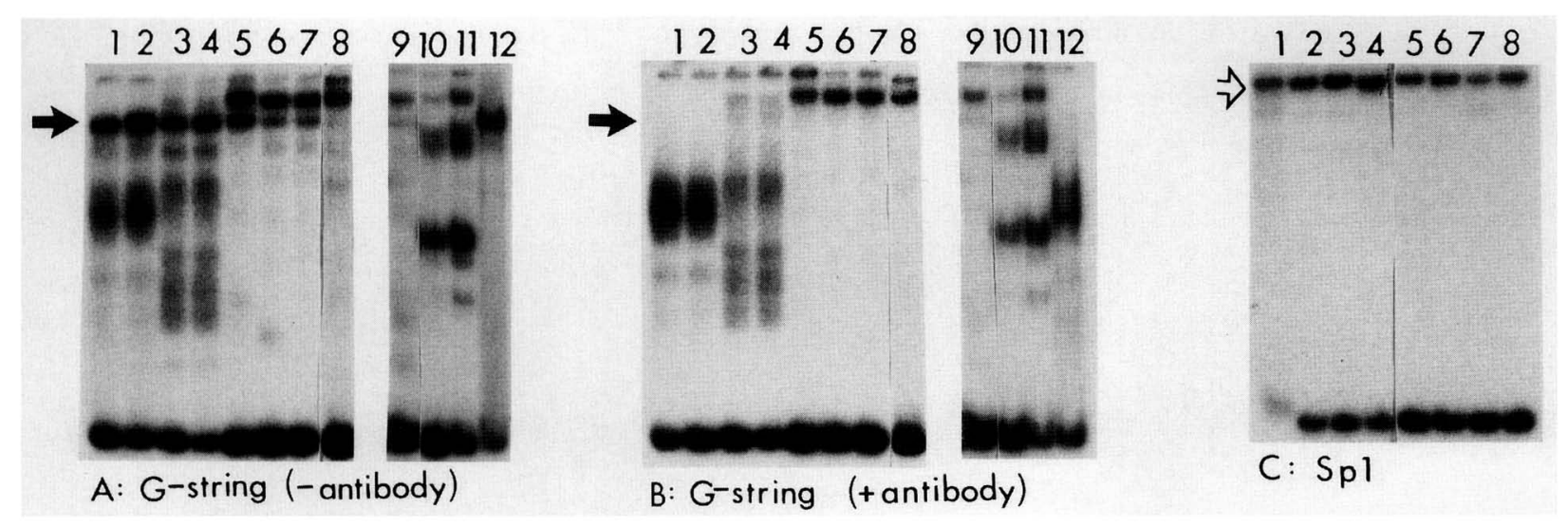

Figure 7. Tissue specificity of BGPl. Each extract was prepared by treating nuclei with $300-400 \mathrm{~mm} \mathrm{NaCl}$; the volume of each extract was chosen to equalize the amount of Spl activity, as detected by gel-shift assay. $(A)$ Gel mobility shift assay using the ${ }^{32}$ P-labeled G-string fragment that lacked the Spl site. Nuclear extracts are from adult chicken erythrocytes (lanes 1 and 2); 12-day chicken embryonic erythrocytes (lanes 3 and 4); 9-day chicken embryonic erythrocytes (lane 5); 5-day chicken embryonic erythrocytes (lanes 6 and 7); chicken heart (lane 8); chicken erythroid precursor line HD3 (lane 9); murine pre-B lymphoma line 38C-13 (lane 10); HeLa cells (lane 11); partially purified BGP1 from the DNA cellulose column fraction (lane 12) marked with the solid vertical arrow in Figure 5. The position of BGPXI is indicated by a solid arrow. $(B)$ Assignment of lanes and experimental conditions are identical to those in $A$, except that $5 \mu \mathrm{l}$ of mAb 2B10-1F8 was added to each extract before addition of the G-string probe. $(C)$ Gel mobility shift assay of the Spl probe, using the same volume of extracts as in $A$. Nuclear extracts are from adult chicken erythrocytes (lane 1); 12-day chicken embryonic erythrocytes (lane 2); 9-day chicken embryonic erythrocytes (lane 3); 5-day chicken embryonic erythrocytes (lane 4); chicken heart (lane 5); HD3 cells (lane 6); 38C-13 cells (lane 7); HeLa cells (lane 8). The position of the complex Sp1X is indicated by an open arrow.

lens are also negative (results not shown). Preincubation of each of these extracts with the mAb 2B10-1F8 blocks the formation of the complex BGPX1 in the chicken erythrocytes (Fig. 7B). The gel-shift patterns formed by extracts from all of the other cells are unaffected by the $\mathrm{mAb}$. These results indicate that BGP1, which forms the BGPX1 complex, is abundant in erythrocytes as early as 9 days after fertilization but is less abundant at earlier stages and absent from nonerythroid cells.

\section{Discussion}

We have used the gel mobility shift assay as a screening method to identify a mAb that interacts with a specific DNA-binding protein, BGP1. This protein binds specifically to the sequence $\mathrm{dG}_{16}$, the $\mathrm{G}$-string, in the nuclease hypersensitive domain of the chicken $\beta$-globin gene. The antibody makes it possible to characterize the binding properties of the protein BGP1 in greater detail, to determine its molecular weight, and to show that it is apparently related in its structure to the general transcriptional regulatory factor Spl, although distinct in its sequence specificity.

Gel mobility shift experiments with erythrocyte nuclear extracts and specific DNA fragments from the $\beta$ globin promoter region have allowed us to identify a number of sequence-specific complexes (Fig. 3) arising from interactions with the regions shown in Figure 1. By using a DNA fragment containing a strong Spl-binding site, we are able to show that some of these complexes arise from interaction with chicken $\mathrm{Spl}$ (see below). However, the major band derived from the G-string fragment does not arise from Spl because (1) mutation of the
G-string sequence to destroy a potential Spl site at its $3^{\prime}$ end has no effect on this gel band pattern; (2) the Gstring and $\mathrm{Spl}$ sites do not compete for each other's binding proteins (Fig. 4); (3) mAb 2B10-1F8 has an affinity for BGP1 at least 10-fold higher; and (4) fractionation of the proteins leads to a separation of their corresponding DNA-binding activities (Fig. 5).

BGPI binds with high affinity to its specific site. This protein does not bind significantly to any of the other $\beta$-globin gene upstream elements. Other G-stringbinding activities are present in the erythrocyte extracts but represent proteins that do not compete effectively for binding of the G-string with BGP1. This is apparent from the fact that the antibody can shunt the DNA from the BGP1 to the competing proteins when DNA is limiting. The complexes formed by the competing proteins are not blocked by the antibody, and the binding of those proteins to the G-string does not depend on the presence of zinc (see below).

\section{Chicken Sp1 and its unexpected binding sites on the $\beta$-globin promoter}

The chicken analog of HeLa Spl was identified by its ability to bind to an Spl site of high affinity taken from the SV40 early promoter region. This identification was supported by the other similarities between the human and chicken Spl proteins: They have the same molecular weight (Briggs et al. 1986), their specific complexes with DNA have the same electrophoretic mobility; they are prevented from binding by $\mathrm{mAb} 2 \mathrm{~B} 10-1 \mathrm{~F} 8$, and they both require $\mathrm{Zn}^{2+}$ for activity.

Chicken Spl binds only weakly to the $3^{\prime}$ terminal por- 
tion of the wild-type G-string but does bind to the polypurine, polypyrimidine, and CACCC sequences within the $\beta$-globin promoter. These sequences form complexes with the same electrophoretic mobility, sensitivity to $\mathrm{mAb} 2 \mathrm{~B} 10-1 \mathrm{~F} 8$, and $\mathrm{Zn}^{2+}$ dependence as those formed with the Spl sequence from SV40. Competition experiments using the latter sequence prove that $\mathrm{Spl}$ is the protein that binds to the polypurine and polypyrimidine tracts, despite the deviation of these sequences from the typical Spl-binding sequence. It has been shown that purified human Spl binds strongly to the polypurine tract in the chicken $\beta$-globin promoter (Evans et al. 1988). The interaction of chicken Spl with this site is also particularly strong.

\section{Implications of the antigenic cross-reactivity of the G- string protein and $S p 1$}

Our survey of a panel of mouse mAbs raised against chicken erythrocyte proteins enriched for binding to the $\beta$-globin gene 5 '-flanking region yielded one antibody (2B10-1F8) that blocks the binding of BGP1 to the Gstring, suggesting that the epitope might be situated within the DNA-binding domain. Remarkably, this antibody also blocks the binding of chicken and HeLa cell Spl to Spl-specific sites (Fig. 3). The cross-reacting antigens BGP1 and Spl further resemble each other in requiring zinc ion for DNA-binding activity, unlike the non-cross-reacting proteins that bind to the palindrome, CAAT, or AGATAAG sequences (Fig. 4). It seems likely that the antibody recognizes an epitope within the DNA-binding domain, even though zinc is not required for antibody binding (results not shown). On the basis of its amino acid sequence and recognition site, it has been concluded that Spl contains three zinc fingers such as those seen in TFIIIA (Miller et al. 1985; Kadonaga et al. 1987; Rhodes and Klug 1988); we suggest that BGP1 may also contain this feature. The difference in affinity of the $\mathrm{mAb}$ for BGP1 and Sp1 presumably reflects diversity within their DNA-binding domains. By this criterion, BGP1 and Sp1 must be more closely related to each other than to TFIIIA, which is not recognized by this $\mathrm{mAb}$ (data not shown).

\section{The role of $B G P 1$}

At the outset of this study, a number of protein-binding regions in the $5^{\prime}$-flanking sequence of the chicken $\beta$ globin gene had been identified by DNA sequencing and footprinting experiments (Fig. 1). Of these, all but the G-string are masked in chromatin structure in both nonerythroid cells and primitive erythrocytes, which do not express $\beta$-globin. The G-string is unique in being free of histone; in these cells, it lies at the boundary between a linker region and the nucleosome that covers the other protein-binding sites (Jackson 1986). At later stages of erythroid development, this nucleosome has been displaced, a nuclease hypersensitive domain has appeared, most of the other unmasked sites are occupied by regulatory proteins, and the $\beta$-globin gene is expressed. The
G-string itself has also become bound by protein at this stage (Jackson and Felsenfeld 1985). We suggest that the binding of a protein to the exposed G-string in erythroid precursors may result in alteration of the stability of the adjacent bound nucleosome and that this may be an important step in the sequence of events leading to the generation of a hypersensitive domain.

BGP1 possesses the requisite properties for such a protein. It binds with high affinity to the G-string, it is present only in erythrocytes, and its abundance correlates with the appearance of the hypersensitive domain and $\beta$-globin expression. Transient expression studies in which the G-string has been deleted from the promoter do not reveal an effect of this element on transcription (J. Nickol, unpubl.). Such behavior would not be surprising for a control factor that acts by altering chromatin structure, because the template in this transient expression assay is probably not packaged correctly as chromatin. The role we tentatively propose for BGP1 has not been demonstrated. However, nucleosome phasing observed in inactive cells in vivo appears to be reconstructible in vitro with cloned promoter DNA fragments and purified histones (Kefalas et al. 1988). With the purification of BGP1 (S. Clark, unpubl.) and the availability of the $\mathrm{mAb}$ that blocks its binding, it should be possible to determine the effects of this protein on chromatin structure.

\section{Materials and methods}

\section{Production of $m A b s$}

mAbs were produced in conjunction with Hazelton Laboratories (Vienna, Virginia). Two BALB/c mice were given three injections each of $1 \mathrm{mg}$ of partially purified extract containing factors binding to the promoter region of the chicken $\beta$-globin gene, isolated on a calf thymus DNA-cellulose column, as described previously (Emerson et al. 1985).

Mouse I was sacrificed after the third injection. Mouse II was given a fourth injection of $100 \mu \mathrm{g}$ of protein purified on a DNA affinity column constructed with pUC8 containing a fragment extending from -303 to +167 of the $5^{\prime}$-flanking region of the chicken $\beta$-globin gene. The $250 \mathrm{~mm}$ ammonium sulfate fraction from the calf thymus DNA-cellulose column, dialyzed to 25 mM ammonium sulfate, was applied to the affinity column, and fractionation was achieved by stepwise elution with increasing concentrations of ammonium sulfate in $20 \mathrm{mM}$ HEPES (pH 7.9), $5 \mathrm{~mm} \mathrm{MgCl}, 0.1 \mathrm{~mm}$ EDTA, $10 \%$ glycerol, $0.1 \%$ Brij-35, $1 \mathrm{~mm}$ dithiothreitol (DTT), and $0.1 \mathrm{~mm}$ phenylmethylsulfonyl fluoride (PMSF). Protein fractions that eluted from the column were assayed by nitrocellulose filter binding, as described (Emerson et al. 1985). Proteins bound specifically to the column eluted between 150 and $200 \mathrm{~mm}$ ammonium sulfate, whereas the bulk of the nonspecifically bound proteins eluted at 100 $\mathrm{mM}$ ammonium sulfate or lower. The $200 \mathrm{mM}$ fraction was enriched 10- to 15-fold over the input for the specifically bound proteins.

Following fusion of splenocytes with P3X-63-Ag8-653c cells (Nowinski et al. 1979), 600 hybridoma supernatants from each mouse were screened by ELISA (Carroll and Stollar 1982), using peroxidase-conjugated goat anti-mouse IgG and IgM (Boehringer Mannheim) as the secondary antibody. Both the crude and the affinity-purified extracts were used as antigens in the ELISA. Positive clones were expanded and rescreened to select for stable lines. Cells positive for the affinity-purified pro- 
tein were tested for nonspecific binding, subcloned by limited dilution, and isotyped. The resulting panel of antibodies was screened further for specificity by interference of the gel shift assay, as described below. Two IgMs (2B10-1F8 and 8E4-1B4) were grown to 1 liter in suspension and enriched further by ammonium sulfate precipitation, followed by chromatography through Sepharose 4B.

\section{Electrophoretic mobility shift assay}

DNA binding was examined by a gel shift assay (Fried and Crothers 1981; Garner and Revzin 1981). Binding reactions contained $50 \mathrm{~mm}$ Tris ( $\mathrm{pH} 8.0$ ), $100 \mathrm{mM} \mathrm{NaCl}, 3 \mathrm{mM} \mathrm{MgCl}_{2}, 1$ $\mathrm{mM} \mathrm{CaCl} 2,1 \mathrm{~mm}$ DTT, $0.0125 \%$ Triton $\mathrm{X}-100,10 \mu \mathrm{g} / \mathrm{ml}$ bovine serum albumin (BSA), 4\% Ficoll-400, 0.004\% bromphenol blue, and $0.004 \%$ xylene cyanol. Unless otherwise specified, each reaction contained $0.2 \mathrm{ng}$ of ${ }^{32} \mathrm{P}$-labeled double-stranded synthetic oligonucleotide of 50 or $43 \mathrm{bp}$ (see Fig. 1), $100 \mathrm{ng}$ of poly[d(AT)] as nonspecific competitor, and $0.5-10 \mu \mathrm{l}$ of protein solution in $20-30 \mu \mathrm{l}$ final volume. Binding reactions were carried out at $25^{\circ} \mathrm{C}$ for $5 \mathrm{~min}$, and electrophoresis was through $8 \%$ polyacrylamide gels (19:1 acrylamide : bis) in $10 \mathrm{~mm}$ HEPES, $10 \mathrm{~mm}$ Tris $(\mathrm{pH} 8.0)$, and $1 \mathrm{~mm}$ EDTA for $1.5 \mathrm{hr}$ at $6.5 \mathrm{~V} / \mathrm{cm}$. Where appropriate, unlabeled olignucleotides were added as specific competitors. Protein was always added last after all the DNA had been mixed. Oligonucleotides were made on an Applied Biosystems synthesizer, gel-purified, and end-labeled with polynucleotide kinase using standard procedures. Gel-shift assays to test for the effect of antibodies, metal chelation, or metals were identical except that protein was preincubated with these agents for $5 \mathrm{~min}$ at $25^{\circ} \mathrm{C}$ before addition of the DNA.

\section{Preparation and analysis of proteins}

Adult chicken erythrocyte proteins used in the mobility shift assays were partially purified, as described by Emerson et al. (1985), with the following modifications. The procedure was scaled up to accommodate a starting volume of 3 liters of adult chicken blood (Pel Freeze, Rogers, Arkansas). Nuclei were given only a minimal wash before extraction with $0.3 \mathrm{M} \mathrm{NaCl}$, and the extract was not precipitated with ammonium sulfate. Fractionation on a DNA-cellulose column (for 3 liters of starting blood, 100 grams of Sigma double-stranded calf thymus DNAcellulose, $4.3 \mathrm{mg}$ of DNA per gram of cellulose, with a column volume of $\sim 500 \mathrm{ml}$ ) was performed by loading in $20 \mathrm{mM}$ HEPES (pH 7.9), $5 \mathrm{mM} \mathrm{MgCl}_{2}, 0.1 \mathrm{~mm}$ EDTA, $10 \%$ glycerol, $0.1 \%$ Brij-35, $1 \mathrm{~mm}$ DTT, and $0.1 \mathrm{~mm}$ PMSF plus $25 \mathrm{~mm}$ ammonium sulfate and eluting with a gradient of $50-150 \mathrm{mM}$ ammonium sulfate in $25 \mathrm{~mm}$ steps, with a final wash of $250 \mathrm{mM}$ ammonium sulfate. Affinity column chromatography was essentially as described (Wu et al. 1987). Nuclear extracts from embryonic chicken erythrocytes and other cell types were prepared in a similar way but were not fractionated. Proteins were electrophoresed according to the method of Laemmli (1970), and silver staining was as described by Wray et al. (1981). For Western blotting, gels were transferred to nitrocellulose for $2 \mathrm{hr}$ at $200 \mathrm{~mA}, 60 \mathrm{~V}$, as described by Towbin et al. (1979). The filter was presaturated with $0.5 \%$ BSA, $0.05 \%$ Triton in TEN [150 $\mathrm{mM} \mathrm{NaCl}, 2 \mathrm{~mm}$ EDTA, $10 \mathrm{mM}$ Tris $(\mathrm{pH} 7.4)$ ] overnight at $4^{\circ} \mathrm{C}$ and then incubated with $3 \mu \mathrm{g} / \mathrm{ml}$ of enriched primary antibody in TEN containing $0.5 \%$ BSA, $0.05 \%$ Triton, and $10 \%$ fetal calf serum for $1 \mathrm{hr}$ at $25^{\circ} \mathrm{C}$. The filter was washed three times with TEN containing $0.1 \% \mathrm{BSA}$ and $0.1 \%$ Triton for $1 \mathrm{hr}$ at $25^{\circ} \mathrm{C}$. The secondary antibody, rabbit anti-mouse IgM (ICN) was incubated with the filter at a concentration of $100 \mu \mathrm{g} / \mathrm{ml}$ in TEN containing $0.1 \% \mathrm{BSA}$ and $0.1 \%$ Triton. The filter was washed as above, incubated with ${ }^{125}$ I-labeled protein $\mathrm{A}$ (sp. act. $9.4 \mu \mathrm{Ci}$ / $\mu \mathrm{g}, \mathrm{NEN}$ ) at $0.05 \mu \mathrm{Ci} / \mathrm{ml}$ in TEN containing $0.1 \%$ Triton, and $0.1 \%$ BSA, rewashed, and dried.

\section{Acknowledgments}

We are grateful to Drs. D.D. Brown and A. Wolffe for the gift of purified TFIILA and Drs. R. Tjian and J. Kadonaga for purified Spl, and to Dr. E. Apella for synthesizing and purifying the wild-type G-string oligonucleotide. We thank the following individuals for gifts of cell extracts: Dr. G. Piatigorski (chicken lens), J. Darlington (12-day chicken embryonic erythrocytes and HD3 cells), R. Lansford (HeLa and B cell), Dr. T. Kimura (5-day chicken erythrocytes), T. Evans (9-day chicken erythrocytes), Dr. M. Minie (chicken heart). We also thank D. Rhodes for valuable comments. This work was supported by a NATO grant awarded to H.G. and G.F.

\section{References}

Berg, J.M. 1986. Potential metal-binding domains in nucleic acid binding proteins. Science 232: 485-487.

Beug, H., S. Palmieri, C. Freudenstein, H. Zentgraf, and T. Graf. 1982. Hormone-dependent terminal differentiation in vitro of chicken erythroleukemia cells transformed by ts mutants of avian erythroblastosis virus. Cell 28: 907-919.

Breathnach, R. and P. Chambon. 1981. Organization and expression of eucaryotic split genes coding for proteins. Annu. Rev. Biochem. 50: 349-383.

Briggs, M.R., J.T. Kadonaga, S.P. Bell, and R. Tjian. 1986. Purification and biochemical characterization of the promoterspecific transcription factor, Sp1. Science 234: 47-52.

Carrol, S.B. and B.D. Stollar. 1982. Inhibitory monoclonal antibody to calf thymus RNA polymerase II blocks formation of enzyme-DNA complexes. Proc. Natl. Acad. Sci. 79: 72337237.

Dierks, P., A. van Ooyen, M.D. Cochran, C. Dobkin, J. Reiser, and C. Weissmann. 1983. Three regions upstream from the cap site are required for efficient and accurate transcription of the rabbit $\beta$-globin gene in mouse $3 \mathrm{~T} 6$ cells. Cell 32: 695-706.

Emerson, B.M. and G. Felsenfeld. 1984. Specific factor conferring nuclease hypersensitivity at the $5^{\prime}$ end of the chicken adult $\beta$-globin gene. Proc. Natl. Acad. Sci. 81: 95-99.

Emerson, B.M., C.D. Lewis, and G. Felsenfeld. 1985. Interactions of specific nuclear factors with the nuclease-hypersensitive region of the chicken adult $\beta$-globin gene: Nature of the binding domain. Cell 41: 21-30.

Evans, T., T. DeChiara, and A. Efstratiadis. 1988. A promoter of the rat insulin-like growth factor II gene consists of minimal control elements. J. Mol. Biol. 199: 61-81.

Fried, M. and D.M. Crothers. 1981. Equilibria and kinetics of lac repressor- operator interactions by polyacrylamide gel electrophoresis. Nucleic Acids Res. 9: 6505-6509.

Garner, M.M. and A. Revzin. 1981. A gel electrophoresis method for quantifying the binding proteins to specific DNA regions. Applications to components of the $E$. coli lactose operon regulatory system. Nucleic Acids Res. 9: 30473060.

Gidoni, D., J. Kadonaga, H. Barrera-Saldana, K. Takahashi, P. Chambon, and R. Tiian. 1985. Bidirectional SV40 transcription mediated by tandem $\mathrm{Spl}$ binding interactions. Science 230: $511-517$.

Hanas, J.S., D.J. Hazuda, D.F. Bogenhagen, F.Y-H. Wu, and C.-W. Wu. 1983. Xenopus transcription factor A requires zinc for binding to the 5S RNA gene. I. Biol. Chem. 258: $14120-14125$. 
Jackson, P.D. 1986. 'Tissue-specific gene regulation and the structural differentiation of the adult chicken $\beta$-globin gene.' Ph.D. thesis, Johns Hopkins University, Baltimore, Maryland.

Jackson, P.D. and G. Felsenfeld. 1985. A method for mapping intranuclear protein-DNA interactions and its applications to a nuclease hypersensitive site. Proc. Natl. Acad. Sci. 82: 2296-2300.

Kadonaga, J.T., K.A. Jones, and R. Tjian. 1986. Promoter-specific activation of RNA polymerase II transcription by $\mathrm{Sp} 1$. Trends Biochem. Sci. 11: 20-23.

Kadonaga, J.T., K.R. Carner, F.R. Masiarz, and R. Tjian. 1987. Isolation of cDNA encoding transcription factor $\mathrm{Spl}$ and functional analysis of the DNA binding domain. Cell 51: $1079-1090$

Kefalas, P., F. Grey, and J. Allan. 1988. Precise nucleosome positioning in the promoter of the chicken adult $B$ globin gene. Nucleic Acids Res. 16: 500-517.

Kemper, B., P.D. Jackson, and G. Felsenfeld. 1987. Proteinbinding sites within the 5' DNase I-hypersensitive region of the chicken $\alpha$ D-globin gene. Mol. Cell. Biol. 7: 2059-2069.

Kohwi-Shigematsu, T. and Y. Kohwi. 1985. Poly(dG)-poly(dC) sequences under torsional stress induce an altered DNA conformation upon neighboring DNA sequences. Cell 43: 199-206.

Laemmli, U.K. 1970. Cleavage of structural proteins during assembly of the head of bacteriophage T4. Nature 227: 680685.

Landes, G.M. and H.G. Martinson. 1982. Transcriptional properties of chicken embryonic erythroid nuclei in vitro. J. Biol. Chem. 257: 11002-11007.

Landes, G.M., B. Villeponteau, T.M. Peibyl, and H.G. Martinson. 1982. Hemoglobin switching in chickens. I. Biol. Chem. 257: 11008-11014.

McGhee, J.D., W.I. Wood, M. Dolan, J.D. Engel, and G. Felsenfeld. 1981. A 200 base pair region at the $5^{\prime}$ end of the chicken adult $\beta$-globin gene is accessible to nuclease digestion. Cell 27: 45-55.

Miller, J., A.A. McLachlan, and A. Klug. 1985. Repetitive zinc binding domains in the protein transciption factor TFIIIA from Xenopus oocytes. EMBO I. 4: 1609-1614.

Myers, R.M., K. Tilly, and T. Maniatis. 1986. Fine structure genetic analysis of a $\beta$-globin promoter. Science 232: 613-618.

Nickol, J.M. and G. Felsenfeld. 1983. DNA conformation at the $5^{\prime}$ end of the chicken adult $\beta$-globin gene. Cell 35: 467-477.

Nowinski, R.C., M.E. Lostrom, M.R. Stone, and W.N. Burnette. 1979. The isolation of hybrid cell lines producing monoclonal antibodies against the P15(E) protein of murine leukemia viruses. Virology 93: 111-126.

Plumb, M.A., V.V. Lobanenkov, R.H. Nicolas, C.A. Wright, S. Zavou, and G.H. Goodwin. 1986. Characterisation of chicken erythroid nuclear proteins which bind to the nuclease hypersensitive regions upstream of the adult $\beta$ - and hatching $\beta$-globin genes. Nucleic Acids Res. 14: 7675-7693.

Rhodes, D. and A. Klug. 1988. 'Zinc fingers': A novel motif for nucleic acid binding. In Nucleic acids and molecular biology (ed. D. Lilley and F. Echstein). Springer-Verlag, Berlin. (in press.)

Schon, E., T. Evans, J. Welsh, and A. Efstratiadis. 1983. Conformation of promoter DNA: Fine mapping of S1 hypersensitive sites. Cell 35: 837-848.

Towbin, H., T. Staehlin, and J. Gordon. 1979. Electrophoretic transfer of proteins from polyacrylamide gels to nitrocellulose sheets: Procedure and some applications. Proc. Natl. Acad. Sci. 76: 4350-4354.

Villeponteau, B., G.M. Landes, M.J. Pankratz, and H.G. Mar- tinson. 1982. Transcriptional properties of chick embryonic erythroid nuclei in vitro. J. Biol. Chem. 257: 11015-11023.

Wray, W., T. Boulikas, V. Wray, and R. Hancock. 1981. Silver staining of proteins in polyacrylamide gels. Anal. Biochem. 118: 197-203.

Wu, C., S. Wilson, B. Walker, I. Dawid, T. Paisley, V. Zimarino, and H. Ueda. 1987. Purification and properties of Drosophila heat shock activator protein. Science 238: 1247-1253. 


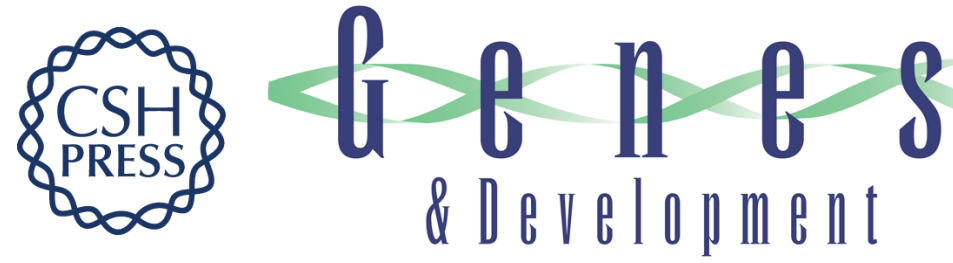

\section{An erythrocyte-specific protein that binds to the poly(dG) region of the chicken beta-globin gene promoter.}

C D Lewis, S P Clark, G Felsenfeld, et al.

Genes Dev. 1988, 2:

Access the most recent version at doi:10.1101/gad.2.7.863

References This article cites 33 articles, 14 of which can be accessed free at:

http://genesdev.cshlp.org/content/2/7/863.full.html\#ref-list-1

License

Email Alerting Receive free email alerts when new articles cite this article - sign up in the box at the top Service right corner of the article or click here.

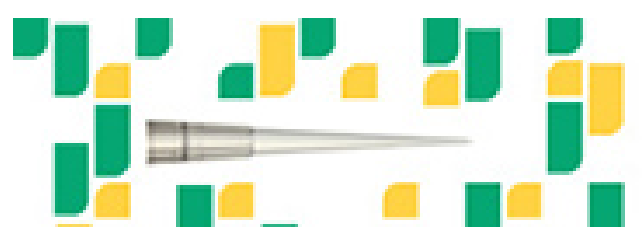

Focused on your science. 